\title{
The Effect of over-taxation and Corruption at Commercial Enterprises in Greece: Evidence from a Survey Experiment
}

\author{
Dimitrios Komninos', Zacharias Dermatis ${ }^{2}$, Athanasios Anastasiou ${ }^{3}$ \\ and Panagiotis Liargovas ${ }^{4}$
}

\begin{abstract}
The problem of tax evasion and tax avoidance is one of the most important issues which Greece has to face. In Greece, research has provided evidence that tax evasion is higher than other countries and this fact burdens the economic situation of the country. Overcrowding in a reluctant economy has many adverse effects and is a brake on sustainable development. High taxes are incentive for tax evasion, causing the state to record revenue losses. This in turn leads to new tax increases, further encouraging tax evasion. The subject of this paper is the over-taxation and its relation to the corruption phenomenon that characterizes the country of Greece. For the needs of this paper, an experimental survey was distributed to commercial enterprises in a prefecture of Peloponnese of Greece. The results of the survey showed that overpopulation and corruption co-exist and are symptoms of a society dominated by a lack of confidence in the state. Both overemphasis and corruption are political and economic problems and well-designed measures to modernize the political system and contribute to their effective treatment.
\end{abstract}

JEL classification numbers: H26, L26, K34.

Keywords: Taxation, Tax evasion, Corruption.

\footnotetext{
${ }^{1} \mathrm{PhD}$ - Department of Management Science and Technology, University of Peloponnese Greece.

${ }^{2} \mathrm{PhD}$ - Department of Management Science and Technology, University of Peloponnese Greece.

3 Assistant Professor - Department of Management Science and Technology, University of Peloponnese Greece

${ }^{4}$ Professor - Department of Economic Studies, University of Peloponnese Greece.
} 


\section{Introduction}

The proper functioning of the institutions of a society are prerequisites for its development. However, there are the phenomena of excessive taxation and corruption, which undermine entrepreneurship, erode human relations and strengthen the clientele state with a variety of adverse socio-economic consequences. Corruption is a political, economic, cultural and moral problem and it is considered as a universal phenomenon that exists in all developed and developing countries, in public and private sectors, as well as in non-profit and charity organizations (Anastasiou et al. (2018).

Corruption and over- taxation remain main problems in developed and developing countries. According to a research of Dalamagas et al. (2019) during the entire period 1995-2015, only two countries (Greece and Italy) appear to overtax their taxpayers. In this case, overtaxing in Greece may be attributed to a drastic reduction in savings.

Greece's inability to collect the tax revenues raises the problem of tax evasion. An example is the over-taxation of alcoholic beverages, which is the main cause of the increase in the smuggling of beverages. Excise duty combined with the increase in VAT has increased the retail price of alcoholic beverages by about $30 \%$.

The continuing increase in the problems caused by tax evasion, coupled with the depopulation of unemployment, smuggling and misery, is causing a shortfall in the treasuries of the State. This loophole is filled with additional taxation and new measures which are burdening citizens and which are a barrier to any prospect of development in the country.

The system of over-taxation which does not support entrepreneurship and investment and is considered unfair by taxpayers is also characterized by the nonprofitability of taxes. In this climate, problematic tax rules create difficulties for entrepreneurship and can lead to unproductive forms of it.

Cornering governments facilitated by unnecessary and unclear laws increase taxation in order to collect money and have cash fluency to serve the customer state, causing additional uncertainty.

Taxpayers choose, due to high taxes, to conceal income and evade tax and are ready to bribe state officials to serve.

According to Nkpoyen et al. (2014), when tax rates increase, businesses will consume resources in their efforts to avoid them. This type of corruption can potentially affect entrepreneurship by preventing "ethical" companies from entering the market or forcing them out. According to this reference is also the Friedman et al (2000) article, which denotes high tax rates, as the main cause of illegal business activity. In interpreting that view, the undertaking therefore chooses to adopt illegal methods in order to avoid the introduction of a high tax burden, thereby improving its financial position.

Another faculty argues that creating grounds for involvement in illegal action are found in the perverse political and social institutions, which govern the economy, such as misconceived bureaucracy, corruption and the rogue justice system. 
Businesses are willing to tax at reasonable rates, but not to tolerate constantly blackmailing and arbitrary demands of officials and officials. Is it not an obstacle to entrepreneurship to find that even a firefighter in the fire safety control of a new facility can demand any amount of money, knowing that the entrepreneur will give in, otherwise his business will be sealed off with greater losses (Wilson, 1996).

According to the above survey, higher tax rates do not appear to be associated with more intensive illegal business. On the contrary, discrimination in the application of laws and the inherent corruption of discrimination, but also pluralism, are seen as factors which contribute more to illegality. Increasing the involvement of companies in illegal activity stimulates the public economy and weakens the ability of the state to protect the right to property. However, according to the same study, the existence of a regulatory framework does not lead to illegal action. For example, the introduction of realistic rules of law on health and safety at work can make a significant contribution to the growth of productivity. A problem arises when the existing regulatory framework is ambiguous and multi-faceted, creating a breeding ground for opacity, corruption, blackmail and, in general, illegality. Here too, the effect is to recognize the reduction in public revenue and the failure to provide public goods which can improve productivity on the market. In principle, there may be a view that high tax rates lead to companies being unlawfully, but the sample of this survey showed that higher tax rates result in more tax revenues, a stronger legislative environment and ultimately a lower level of illegal activity.

The table below shows the tax rates for the income tax of natural and legal persons and Value Added Tax (VAT) for the countries of the European Union. VAT is considered to be more effective than progressive income taxation because it can raise revenue without interfering with economic adjustment and development (Bräutigam 2008). 
Table 1: Tax rates of European countries in 2020

\begin{tabular}{|l|c|c|c|}
\hline \multicolumn{1}{|c|}{ Countries } & $\begin{array}{c}\text { Corporate Tax } \\
\text { rate (\%) }\end{array}$ & $\begin{array}{c}\text { Personal Income } \\
\text { Tax rate (\%) }\end{array}$ & $\begin{array}{c}\text { Sales Tax rate } \\
(\mathbf{\%})\end{array}$ \\
\hline Austria & 25 & 55 & 20 \\
\hline Belgium & 29 & 53,7 & 21 \\
\hline Bulgaria & 10 & 10 & 20 \\
\hline France & 33,3 & 45 & 20 \\
\hline Germany & 30 & 45 & 16 \\
\hline Denmark & 22 & 55,8 & 25 \\
\hline Greece & $\mathbf{2 4}$ & $\mathbf{4 5}$ & $\mathbf{2 4}$ \\
\hline Estonia & 20 & 20 & 20 \\
\hline United Kingdom & 19 & 45 & 20 \\
\hline Ireland & 12,5 & 48 & 23 \\
\hline Spain & 25 & 45 & 21 \\
\hline Italy & 24 & 43 & 22 \\
\hline Croatia & 18 & 36 & 25 \\
\hline Cyprus & 12,5 & 35 & 19 \\
\hline Latvia & 20 & 31,4 & 21 \\
\hline Lithuania & 15 & 15 & 21 \\
\hline Luxemburg & 18,19 & 45,8 & 17 \\
\hline Malta & 35 & 35 & 18 \\
\hline Netherlands & 25 & 51,75 & 21 \\
\hline Hungary & 9 & 15 & 27 \\
\hline Poland & 19 & 32 & 23 \\
\hline Portugal & 21 & 48 & 23 \\
\hline Rumania & 16 & 10 & 19 \\
\hline Slovakia & 21 & 25 & 20 \\
\hline Slovenia & 19 & 50 & 22 \\
\hline Sweden & 21,40 & 57,2 & 25 \\
\hline Czech Republic & 19 & 22 & 21 \\
\hline Finland & 20 & 53,75 & 24 \\
\hline Euro area & $\mathbf{2 3 , 3}$ & $\mathbf{4 1 , 5}$ & $\mathbf{2 0 , 8}$ \\
\hline European Union & $\mathbf{2 1 , 3}$ & $\mathbf{3 8 , 6}$ & \\
\hline & & & \\
\hline
\end{tabular}




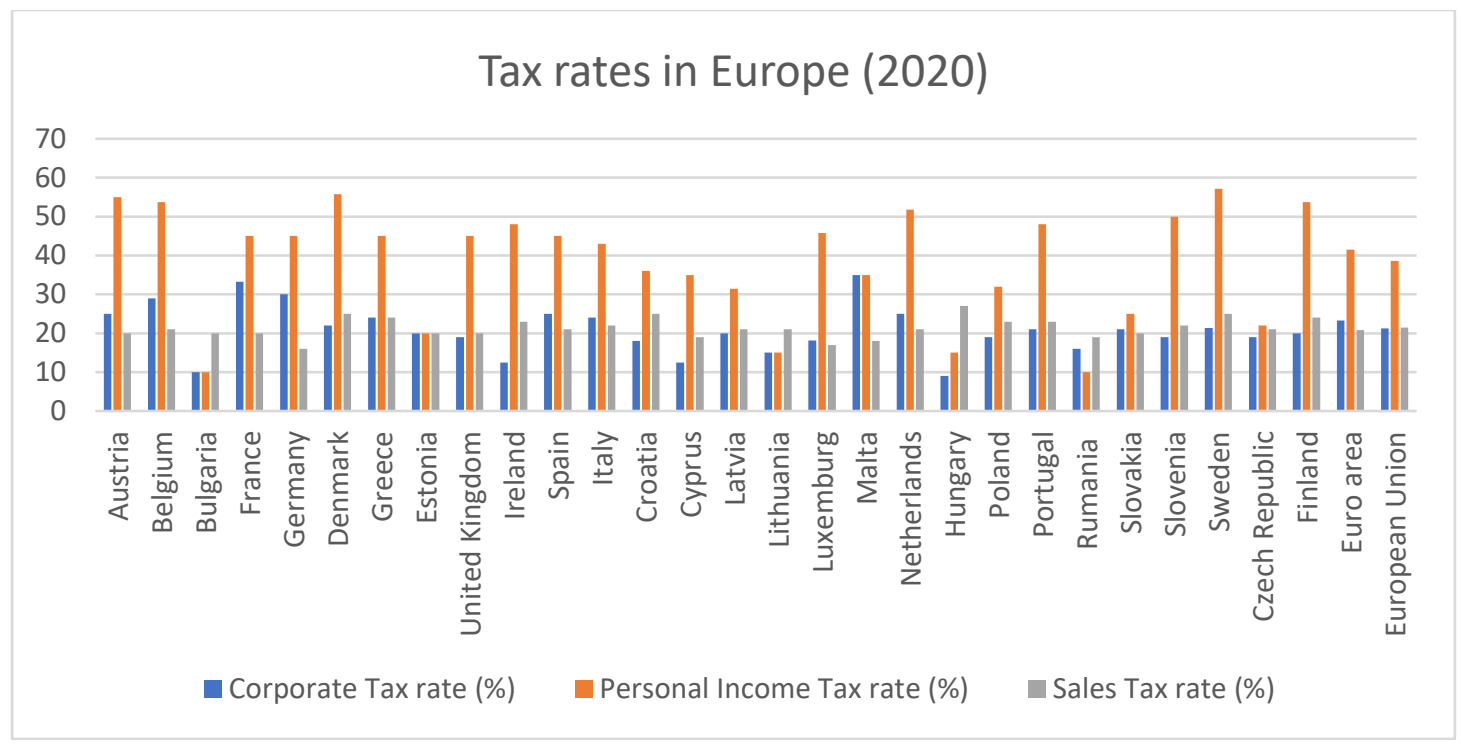

Figure 1: Tax rates in European Countries (2020)

The way in which the tax system is managed is of crucial importance in any case. A top example of the importance of the quality of administration and, in this case, of taxation, is Russia, which, although it has established an average level of tax rates, due to the level of corruption observed in its tax administration, is showing a high level of illegal action. Due to maladministration, businesses are basically pushed into illegality in order to survive, which is a disincentive to the development of business in the region. Foreign companies will not choose to settle in countries where there is maladministration - as is Ukraine during Kaufman (2007) - but domestic companies with no other option will be forced to break the law.

This work seeks to describe the Greek reality and to present proposals for tackling the phenomena. The goal of this research is to build deep, rich and thick narratives and analysis regarding the perceptions, attitudes and patterns of thought of the participants in this survey.

The questions this article seeks to address are:

- How does the tax framework (high tax rates, electronic means of payment) help to tackle tax evasion?

- Bureaucracy and multiculturalism create opportunities and incentives for the development of corruption phenomena?

- Does the choice of fiscal policy mix in Greece, which is mainly based on increased taxation, contribute to the emergence of corruption?

- How can over-taxation and corruption in business be reduced?

This paper is organized as follows: In Chapter 2 we review a few papers that provide a theoretical background of the present study. In chapter 3 we present and explain 
the methodology which is used. Chapter 4 comprises of the results and discussion of this study. Finally, in chapter 5 we conclude the whole study.

\section{Literature review}

By studying the international and domestic literature in an attempt to capture a scientifically documented definition of the concept of "corruption" one quickly perceives the absence of generally accepted definitions. It is a phenomenon that is timeless in societies regardless of development, glory, culture and power. Reports by Plutarhos and Aristotle on corruption phenomena suggest the latter has a presence of at least 2,500 years in the Greek area.

The difficulty in formulating the definition of corruption becomes even clearer if you resort to the texts of the International Conventions on corruption. From the point of view of the literature 'corruption' means the requirement, the offer, the provision, the acceptance, directly or indirectly, of a gift or any other unintended benefit affecting the proper performance of a task or the required behavior of the recipient of the present or the unsuitable benefit or the promise of such a benefit' (Raikos, 2006).

Schleifer and Vishny (1993) refer that when state authority is low, overtaxing via corruption can slow economic development. So, as we can understand, corruption is one of the major challenges to the growth of the economic system.

According to Philip (1997) definitions of "corruption" can be categorized as those focusing on: (a) the holding of a public position; (b) the failure of public interest; and (c) the market definitions. Definitions containing concepts such as 'public opinion' or 'rule of law' have also been recorded in the literature but, according to Philip, fall into any of the above categories.

For example, the first category includes the definition of Nye (1967) according to which: "Corruption is behavior that deviates from the formal tasks of a public position, in the expectation of gaining private benefit (staff, family) in the form of economic gain or improving social status. 'The Convention directly infringes rules prohibiting the exercise of specific forms of private influence. This includes corruption, nepotism and embezzlement." According to Philip, Nye refrains from mentioning the public interest in his definition, as he does not want to create confusion between the phenomenon and the consequences of that.

The second category includes the definition of Carl Friedrich (as referring to Philip), according to which "corruption occurs in every case the body of power is convinced by illegal pecuniary or other consideration to take action which benefits the person providing the consideration and thereby damages the public and the interests of the public."

Market definitions attempt to distance themselves from partially subjective evaluation crises, such as public position and public interest, and to approach corruption and in general political analysis by economic methods and models. The definition of ' $\mathrm{N}$ ' also moves in this context. Leff (as referred to in M. Philip), according to which: corruption is that illegal 'institution' used by natural persons or 
groups of persons to influence the decisions/actions of bureaucracy. So the existence of corruption in itself demonstrates that these groups are more involved in the decision-making process than if the situation were different, that is, if there was no corruption.

According to the definition of VanKlaveren (referred to as M. Philip): "...corruption exists when a public worker abuses his power to obtain an extra income ...One therefore perceives the concept of corruption from the point of view of the public servant who treats his service as an enterprise, the value of which he will try to maximize."

Regardless of the form of corruption or how it is measured, its impact on both developed and developing countries is detrimental. Corruption is linked to the country's lack of competitiveness, its failure to attract and sustain foreign direct investment, the twin of fiscal debt and deficit, the breakdown of social cohesion, the justice deficit, the humanitarian crisis, the gray economy, tax evasion.

According to the United Nations in developing countries, corruption is a brake on national, social, economic and political progress. Public funds are inefficiently allocated, capable and honest citizens feel frustrated and the general climate of public distrust is increasing and the lack of public confidence is increasing. As a result of this situation, financial aid from foreign countries is declining, productivity is reduced and the political stability of the country and its economic development is undermined, since corruption is causing significant amounts of money to be withheld from the West. Political instability is increasing in this way, which in turn results in inadequate infrastructure, education and health. This reality, according to the United Nations, is not very far away in developed countries.

The over-taxation in addition to creating economic lassitude in the population leads to social reactions to an ineffective government. This is caused by the ratio of taxable income and tax (Tucker,2013). The increase in tax rates through tax policy differentiation (Hammar, et.al, 2009) is ineffective for increasing tax revenues and managing the economy. Finding the optimal tax rate is a prerequisite for a sustainable tax policy (Laffer, 2004).

A country's level of corruption affects the composition of public spending included in a budget. In particular, corruption distorts the composition of public expenditure in relation to the necessary expenditure in the field of education and health, as these costs do not offer the same possibilities for illegal access. The costs of training for school equipment, for example, do not require any particular technology and can be provided by a large number of suppliers. In contrast to major infrastructure or defense equipment, the demands are high and the opportunities for bribery are similar. In the field of education in particular, it is therefore relatively difficult to obtain bribes. Education expenditure in many countries does not exceed $4 \%$ of GDP.

According to Nkpoyen et.al (2014), when tax rates increase, businesses will consume resources in their efforts to avoid them. This type of corruption can potentially affect entrepreneurship by preventing "ethical" companies from entering the market or forcing them out. Also, according to Friedman et al (2000), there is 
the school that denotes high tax rates as the main cause of illegal business activity. In interpreting that view, the undertaking therefore chooses to adopt illegal methods in order to avoid the introduction of a high tax burden, thereby improving its financial position.

According to the above survey, higher tax rates do not appear to be associated with more intensive illegal business. On the contrary, discrimination in the application of laws and the inherent corruption of discrimination, but also pluralism, are seen as factors which contribute more to illegality. Increasing the involvement of companies in illegal activity stimulates the public economy and weakens the ability of the state to protect the right to property. However, according to the same study, the existence of a regulatory framework does not in itself lead to illegal action. For example, the introduction of realistic rules of law on health and safety at work can make a significant contribution to the growth of productivity. A problem arises when the existing regulatory framework is ambiguous and multi-faceted, creating a breeding ground for opacity, corruption, blackmail and, in general, illegality. Here too, the effect is to recognize the reduction in public revenue and the failure to provide public goods which can improve productivity on the market. In principle, there may be a view that high tax rates lead to companies being unlawfully, but the sample of this survey showed that higher tax rates result in more tax revenues, a stronger legislative environment and ultimately a lower level of illegal activity.

In the case of Greece, there are surveys which demonstrate in the clearest possible way the importance of the proper functioning of the institutions, as a guarantee of the functioning of the markets and as a precondition for the development of business. Ineffective institutions have been identified as obstacles to democracy and the effective functioning of the free market economy (Bitros \& Karagiannis 2013, Petrou \& Daskalopoulou 2014, as mentioned in Daskalopoulou (2016). 
The over taxation applied has the following consequences:

Table 2: Effects of over-taxation

\begin{tabular}{|c|c|}
\hline Effects & Description \\
\hline $\begin{array}{l}\text { Disincentive to the } \\
\text { competitiveness of the } \\
\text { economy }\end{array}$ & $\begin{array}{l}\text { Competitiveness is mainly burdened by taxation } \\
\text { in conjunction with other factors such as the level } \\
\text { of insurance deductions, bureaucracy and } \\
\text { distortions in the structure of the economy. }\end{array}$ \\
\hline $\begin{array}{l}\text { Exhaustion of financial } \\
\text { resources }\end{array}$ & $\begin{array}{l}\text { It exhausts the resources that could be allocated } \\
\text { to consumption/savings, further resulting in the } \\
\text { difficulty of reviving the Greek economy. It is } \\
\text { difficult because the proceeds of taxes are not } \\
\text { used to finance development projects and } \\
\text { investments, and the overall output of the country } \\
\text { is not increased by public spending either. }\end{array}$ \\
\hline $\begin{array}{l}\text { Decrease in disposable } \\
\text { income and demand }\end{array}$ & $\begin{array}{l}\text { High taxation (direct and indirect) reduces } \\
\text { consumer demand and, in particular, high VAT } \\
\text { rates are reduced to concealing trade by } \\
\text { strengthening offensive behavior. }\end{array}$ \\
\hline Raising of capital & $\begin{array}{l}\text { It draws valuable private capital that could be } \\
\text { made available for investment or consumption } \\
\text { and/or savings. }\end{array}$ \\
\hline Free trade & $\begin{array}{l}\text { A large proportion of cigarettes, alcoholic } \\
\text { beverages and fuel consumed is trafficked. }\end{array}$ \\
\hline Reverse Balances & $\begin{array}{l}\text { It overturns the balance between direct and } \\
\text { indirect taxes in favor of the latter at the expense } \\
\text { of weak citizens. }\end{array}$ \\
\hline $\begin{array}{l}\text { Continuous increase in } \\
\text { arrears to the State. }\end{array}$ & $\begin{array}{l}\text { The exhaustion of fiscal capacity has led many } \\
\text { households to poverty. }\end{array}$ \\
\hline Inflation growth & $\begin{array}{l}\text { As part of the effort to achieve fiscal } \\
\text { consolidation and reduce deficits, indirect taxes } \\
\text { have increased, which have contributed to an } \\
\text { increase in inflation. }\end{array}$ \\
\hline Influence on real estate & $\begin{array}{l}\text { The over-taxation of real estate has led to a } \\
\text { collapse in real estate, with property prices } \\
\text { falling. }\end{array}$ \\
\hline $\begin{array}{l}\text { Undesirable effects on } \\
\text { employment and in general } \\
\text { on the production process. }\end{array}$ & $\begin{array}{l}\text { The inability of companies to meet tax } \\
\text { obligations due to high tax rates leads many to } \\
\text { inefficiencies and job losses, further increasing } \\
\text { unemployment. }\end{array}$ \\
\hline Lack of development & $\begin{array}{l}\text { It does not provide the right economic } \\
\text { environment for high sustainable growth. }\end{array}$ \\
\hline
\end{tabular}




\section{Methodological Framework}

\subsection{Structure of the questionnaire}

The corruption perception is based on subjective experiences of individuals or groups. Therefore, the measurement of corruption is carried out by specialized business groups through appropriate questionnaires. The survey results are measurable in the form of simple or composite indicators (Anastasiou et al, 2018). The questionnaire consists of three areas: Section A the investigation of evidence of over-taxation, and Section B related to corruption, Section C are about proposals to reduce cases of over-taxation and corruption in business.

\subsection{Population - Sample of survey}

The research population is commercial enterprises of all legal forms, established and operating in the Regional Unit of Arcadia, and reaching numerically in 1984, according to data from Arcadia Chamber. The research, which took place during the period January - February 2019, carried out a sample of 220 commercial companies. In the present research the index Cronbach Alpha is 0,756.

Totally 157 men and 63 women participated in the survey. The majority of respondents (61.9\%) are aged between 31 and 50. As regards the educational level of the participants, $6.7 \%$ of primary school graduates, $53.2 \%$ of graduates are secondary school graduates, and $40.1 \%$ of university graduates.

Also, $77.7 \%$ of respondents surveyed are owners of the companies, 9.5\% are employees, $5.9 \%$ heads of department, $4.5 \%$ heads of management and $2.3 \%$ heads of sector. In addition, $32.3 \%$ of respondents replied that the company's operating years exceed 20 years, $19.5 \%$ from $1-5$ years, $18.2 \%$ from $11-15$ years, $15.5 \%$ from 6-10 years, $14.5 \%$ from $16-20$ years.

The majority of the sample $(62.7 \%)$ replied that the company's gross income is $<150.000 .00 €, 11.8 \%$ from $150.001 €-300.000 €$, at $11.7 \%$ with company revenue $>450.000,3.7 \%$ from $300.001 €$ to $450.000 €$, and $10 \%$ replied "I don't know/I don't answer".

Finally, $82.3 \%$ of enterprises employ $1-10$ workers, $14.1 \%$ of $11-50$ workers, $2.7 \%$ of 51-250 workers and only $0.9 \%$ more than 250 workers.

\subsection{Analysis of the replies}

A large part of the $63.2 \%$ sample indicates that it is "quite" to "very well" informed about tax liabilities and entitlements. The vast majority of respondents $(89.6 \%)$ are unhappy with the current tax system in our country, and a large proportion, which is also close to $88.1 \%$, says that the level of tax burden is "quite" to "very" high.

This is where the growing tax dissatisfaction and the prevailing sense of unfair on the part of the operators can be seen.

Also, a large part of $73.2 \%$ says that if there was a reduction in tax rates, tax evasion would be reduced.

These replies confirm that over-taxation is a key cause and incentive for tax evasion. An equal of $69.1 \%$ of respondents argue that the introduction of new taxes and rates 
will increase the state's revenues from "none" to "little".

This view is justified in view of the over in debt endless of households and businesses, the contraction of incomes and the failure to fulfill tax and insurance obligations. Any increase in taxation will not generate any additional revenue. This is also linked to the fact that taxpayers are not satisfied with the current tax system in our country because they do not believe in the payback and effective use of taxes. A figure of $76.8 \%$ indicates that daily transactions have been facilitated by the use of electronic means of payment.

$58.6 \%$ of respondents replied that if POS had not been mandatory, they would not have allowed their customers to pay them by card. This is an indication of the mentality and lack of fiscal consciousness that exists. It has been realized that the increase of electronic transactions against those with cash is consistent with the increase of transparency in the transactions and helps in the reduction of tax evasion, since all electronic payments are identified more easily. Actually, according to the Report of the Institution of Economic and Industrial Researches (2015), the increase of income taxes via the restriction of tax evasion plays also fundamental role in the effort of rationalization of public finances and return of Greek economy into development (Liargovas et al, 2018).

With regard to the current tax framework, most $85.4 \%$ of respondents consider that it contributes from "none" to "little" in tackling tax evasion, $82.8 \%$ "not at all" to "little" in reducing the gray economy, $85.5 \%$ "not at all" to "little" in setting up and developing businesses, 87.3\% "not at all" to "little" in attracting investors to growth $72.3 \%$ "not at all" to "little" in the growth of state revenue, $70.9 \%$ "not at all" to "little" in reducing the bureaucratic process, $63.2 \%$ "not at all" to "little" in the speed and efficient serving of taxpayers, $85.9 \%$ "not at all" to "little" in strengthening taxpayers' tax conscience, $872.2 \%$ "none" to "little" in shaping the entrepreneur's confidence in the state, $85.9 \%$ "none" to "little" in curbing corruption. These answers demonstrate the ineffectiveness of the tax framework.

A stable tax framework is needed to attract capital and help the country's employment and competitiveness. The establishment of conditions of trust between the entrepreneur and the State will contribute positively to attracting investors to the country's development plans. Reducing bureaucracy will make a positive contribution to the speed and efficiency of the service of taxpayers.

There is now an urgent need for a complete reform of the fiscal framework with a primary focus and a view to the economic well-being and development of the country.

According to the respondents' replies, the lack of stability in the tax framework (68.7\%), the existence of a large number of tax laws and circulars $(71.8 \%)$, the overtaxation of businesses (78.2\%), high social security contributions (69.1\%), contribute "very" to "very much" in corruption. The ability to collect public revenue has been affected by a long history of complicated legislation, maladministration, political intervention practices and generous amnesty, with chronic misapplication. To see how complex the tax administration is today, let's see how many circulars the Ministry of Finance publishes each year (Rapanos et al, 2014:626): in 2009 it 
issues 54 circulars, in 2010 it issues 277, in 2011 it publishes 457, in 2012 issues 513 circulars and in 2013 until 31/10/2013 it issues 695 circulars. It is noted that over the past 18 months, 94 laws have been passed in the entire Public Administration and over 400 interpretative circulars have been issued (Papandropoulos, 2015:28). As a result, both taxpayers and tax administration officials are prevented from following changes and overall developments in a tax issue and thus find difficulty in interpreting and properly implementing them (Liargovas, et al., 2019).

A large $74.1 \%$ of respondents argue that corruption affects healthy competition between businesses. The cost of corruption is high, it increases the cost of goods and highlights social inequalities.

Regarding the legal framework related to corruption in accordance with the views of the majority of respondents, the simplification and codification of tax legislation, the tightening of disciplinary legislation and the reduction of bureaucracy will make a major contribution to the fight against corruption.

With regard to the prevention and awareness of citizens, the introduction of courses in tax awareness and integrity education and the strengthening of information online are elements which will contribute "very much" to the improvement of services to citizens, the establishment of a sense of trust and the prevalence of the principle of transparency.

\subsection{Correlations between statistic variables}

In order to complete this research effort, we will use the SPSS Ver 26 statistical program. Through the SPSS program and the following linear regression analyzes, we are led to formulate the models that express the relationship between our variables.

The values of these variables will be used to study the correlation of the variables, as shown by the literature review.The research framework examines the degree of correlation between:

A. The degree of satisfaction with the current tax system (H1) and The degree of increase of the State revenues with the introduction of new increased taxes and tax rates $(\mathrm{H} 2)$

\begin{tabular}{|l|c|c|c|c|}
\hline & & & H1 & H2 \\
\hline Spearman's rho & H1 & Correlation Coefficient & 1,000 & $\mathbf{0 , 4 0 9}$ \\
\hline & & Sig. (2-tailed) & & .000 \\
\hline & & N & 220 & 220 \\
\hline & H2 & Correlation Coefficient & $\mathbf{0 , 4 0 9}$ & 1,000 \\
\hline & & Sig. (2-tailed) & .000 & \\
\hline & & N & 220 & 220 \\
\hline
\end{tabular}


B. The degree of satisfaction with the current tax system (H1) and

Degree of contribution of the tax framework to the establishment and development of companies (H3)

\begin{tabular}{|c|c|c|c|c|}
\hline & & & H1 & H3 \\
\hline Spearman's rho & H1 & Correlation Coefficient & 1,000 & $\mathbf{0 , 4 4 3}$ \\
\hline & & Sig. (2-tailed) & & .000 \\
\hline & & N & 220 & 220 \\
\hline & H3 & Correlation Coefficient & $\mathbf{0 , 4 4 3}$ & 1,000 \\
\hline & & Sig. (2-tailed) & .000 & \\
\hline & & N & 220 & 220 \\
\hline
\end{tabular}

C. The degree of contribution of the tax framework to attracting investors to the country's development plans (H4) and

The degree of contribution of the tax framework to the formation of conditions of trust of the entrepreneur to the State (H5)

\begin{tabular}{|c|c|c|c|c|}
\hline & & & H4 & H5 \\
\hline Spearman's rho & H4 & Correlation Coefficient & 1,000 & $\mathbf{0 , 6 3 4}$ \\
\hline & & Sig. (2-tailed) & & .000 \\
\hline & & N & 220 & 220 \\
\hline & H5 & Correlation Coefficient & $\mathbf{0 , 6 3 4}$ & 1,000 \\
\hline & & Sig. (2-tailed) & .000 & \\
\hline & & N & 220 & 220 \\
\hline
\end{tabular}

D. Degree of contribution of the tax framework to the reduction of the bureaucratic process (H6) and

Degree of contribution of the tax framework to the speed and efficiency of service to taxpayers. ( $\mathrm{H} 7)$

\begin{tabular}{|c|c|c|c|c|}
\hline & & H6 & H7 \\
\hline Spearman's rho & H6 & Correlation Coefficient & 1,000 & $\mathbf{0 , 7 2 6}$ \\
\hline & & Sig. (2-tailed) & & .000 \\
\hline & & N & 220 & 220 \\
\hline & H7 & Correlation Coefficient & $\mathbf{0 , 7 2 6}$ & 1,000 \\
\hline & & Sig. (2-tailed) & .000 & \\
\hline & & N & 220 & 220 \\
\hline
\end{tabular}


E. Degree of contribution of the lack of stability of the tax framework to the occurrence of corruption (H8) and

Degree of contribution of the existence of a large number of tax laws and circulars to the occurrence of corruption. (H9)

\begin{tabular}{|c|c|c|c|c|}
\hline & & H8 & H9 \\
\hline Spearman's rho & H8 & Correlation Coefficient & 1,000 & $\mathbf{0 , 8 3 9}$ \\
\hline & & Sig. (2-tailed) & & .000 \\
\hline & & N & 220 & 220 \\
\hline & H9 & Correlation Coefficient & $\mathbf{0 , 8 3 9}$ & 1,000 \\
\hline & & Sig. (2-tailed) & .000 & \\
\hline & & N & 220 & 220 \\
\hline
\end{tabular}

F. Degree of contribution to the awareness of students about the effects of corruption, with the introduction of tax courses in education. (H10) and Degree of contribution of the acquisition of tax awareness to the tax administration in reducing corruption. (H11)

\begin{tabular}{|c|c|c|c|c|}
\hline & & H10 & H11 \\
\hline Spearman's rho & $\mathbf{H 1 0}$ & $\begin{array}{c}\text { Correlation } \\
\text { Coefficient }\end{array}$ & 1,000 & $\mathbf{0 , 6 9 9}$ \\
\hline & & Sig. (2-tailed) & & .000 \\
\hline & $\mathbf{H 1 1}$ & $\begin{array}{c}\text { Correlation } \\
\text { Coefficient }\end{array}$ & $\mathbf{0 , 6 9 9}$ & 1,000 \\
\hline & & Sig. (2-tailed) & .000 & \\
\hline & & $\mathrm{N}$ & 220 & 220 \\
\hline
\end{tabular}

Observing the above correlation tables, we conclude that there is a linear correlation for all six pairs of variables. Specifically, the research showed that:

a) "The introduction of new taxes and rates in relation to the current tax system of our country will not lead to an increase in State revenues" (Spearman rate of 0.409$)$.

b) "The tax system in its current form does not contribute positively to the establishment and development of businesses" (Spearman rate of 0.443).

c) "The tax framework in its current form does not contribute positively to the formation of conditions of trust of the entrepreneur to the State, therefore it is not possible to attract investors in the development plans of the country" (Spearman coefficient with a value of 0.634 ).

d) "The tax framework in its current form with the bureaucratic procedure it applies does not contribute positively to the faster and more efficient service 
of taxpayers" (Spearman rate of 0.726).

e) "The existence of a large number of tax laws and circulars does not contribute to the reduction of corruption" (Spearman rate of 0.839).

f) "The introduction of tax education courses in education contributes positively to the acquisition of tax awareness and confidence in the tax administration as well as to the awareness of students about the effects of corruption and therefore contributes effectively to the reduction of corruption.

\section{Conclusion}

The current mix of fiscal policy in our country, which is based on increased taxation, is a growth inhibition. It contributes to corruption, encourages tax evasion by recording losses in state revenues, creates needs for new tax hikes and restricts incentives for investment. The main reason for the increase in tax evasion is, therefore, over-taxation, and only the reduction of taxation, coupled with other incentives for the self-employed, can lead to a solution to the problem.

The vicious circle only breaks with booming growth through measures that make tax evasion unprofitable so that it is done as quickly as possible, less the need for high tax rates.

A reduction in the tax burden requires the creation of a fiscal area by widening the tax base and reducing government expenditure. The emphasis must be on containing and reducing non-productive costs and making more efficient use of public property.

A program of simultaneous increase in productivity in the State and a reduction in tax evasion by reliable tax collection mechanisms, in conditions of growth through profitable private investment, to compensate for the effect of combating tax evasion, will allow tax relief by reducing tax rates on a permanent basis.

Achieving growth requires the creation of a business-friendly environment in order to improve the country's competitiveness through structural reforms, market liberalization, foreign capital inflows for investment.

Extremely important for the sustainability of structural reforms is the fight against corruption, because corruption and low growth are mutually reinforcing.

Fiscal policy should support growth by establishing a stable internationally competitive and socially fair tax system. The level of compliance will increase if the government implements a proper tax policy within which the fight against tax evasion and corruption will be imperative priorities. The fight against tax evasion, combined with the establishment of good administration, is an indispensable precondition for the sustainable development of a society.

In Greece in times of economic crisis, but also unprecedented value crisis, the way out is a fact that it cannot emerge from sterile legislative regulations. In order to rationalize public life and relaunch the local economy, profound intersections of the 
system and a fundamental change in culture are required.

Acknowledgments: We are grateful to Aikaterini Kamari, MSc, Department of Economic Studies, University of Peloponnese Greece, for her contribution to the research part of this paper. 


\section{References}

[1] Anastasiou, A., Papageorgiou, C., Kalamara, E., Komninos, D., Dermatis, Z., and Liargovas, P. (2018). Corruption Perception Index (CPI) as an index of economic growth for European countries. Theoretical Economics Letters, 2018, $8,524-537$

[2] Bräutigam, D. (2008). Introduction: Taxation and state-building in developing countries. In D. Bräutigam,O.-H. Fjeldstad \& M. Moore (eds), Taxation and state-building in developing countries: Capacity and consent. Cambridge: Cambridge University Press

[3] Dalamagas, B., Palaios, P., and Tantos, S. (2019). A new approach to measuring tax effort. Economies, 2019, 7, 77

[4] Daskapoloulou, I. (2016). Rent seeking or corruption? An analysis of income satisfaction and perceptions of institutions in Greece, Elsevier The Social Science Journal.

[5] Festus Nkpoyen, Bassey Glory Eteng, Uyang Francis Abul (2014). Entrepreneurships, Corruption and the Challenge of Development in Nigeria (2014) European Journal of Business and Social Sciences, Vol. 3, No.3 , pp 104-112.

[6] Friedman, E, Johnson, S. and Kaufmann, D. (2000). Zoido-Lobaton P. Dodging the grabbing hand: the determinants of unofficial activity in 69 countries Journal of Public Economics 76, ( 459-493).

[7] Hammar, H., Jagers, S.C. and Nordblom, K. (2009) Perceived Tax Evasion and the Importance of Trust. The Journal of Socio-Economics, 38, 238-245.

[8] Kaufmann, D., Kraay, A. and Mastruzzi, M. (2007). Measuring Corruption,: Myths and Realities, World Bank: Poverty Reduction and Economic Management, April 2007, (39603 - 273.)

[9] Laffer, A.B. (2004) The Laffer Curve: Past, Present and Future. Article No. 1765, The Heritage Foundation Publications, 1-16.

[10] Liargovas, P., Papageorgiou, C., Kalamara, E., Komninos, D., Dermatis, Z., and Anastasiou, A. (2018). The Benefits of Use of Plastic Money in Greece and the EU: Case Study of Use of Plastic Money. from the Elderly. Theoretical Economics Letters, 2018, 8, 793-805

[11] Liargovas, P., Anastasiou, A., Komninos, D., and Dermatis, Z. (2019). The contribution of electronic tax transactions to increasing the productivity of Greek Tax Administration and serving services for citizens and businesses. China-USA Business Review. Volume 18, N. 4

[12] Nye J. S. (Jun., 1967). Corruption and Political Development: A Cost-Benefit Analysis, The American Political Science Review. Vol. 61, No. 2, ( pp. 417427).

[13] Papandropoulos, A. (2015). Politeness means corruption. Magazine Manager. 29

[14] Philip, M. (1997). Defining Political Corruption, Political Studies Association. XLV 436-462 Blackwell Publishers 
[15] Raikos, D. (2006). Public Administration and Corruption. Athens: Publications Sakkoula

[16] Rapanos, B., and Kaplanoglou, G. (2014).

Taxation and economic development

[17] Sheifer, A., and Vishny, R. (1993).

Corruption. Quarterly Journal of Economica. 108(3): 599-617.

[18] Tucker, I.B. (2013) Survey of Economics. South-Western College Publication, Chula Vista.

[19] Wilson, D., (1996). Acer Computer in Russia, Fuqua School of Business, Duke University. 